\title{
The indicators of the bone tissue mineralization abnormalities in women with coronary artery disease in the post-menopausal period
}

\author{
N. S. Mykhailovska, I. O. Stetsiuk
}

Zaporizhzhia State Medical University, Ukraine

Key words: coronary artery disease, postmenopausal period, osteoporosis, osteopenia, metabolic diseases, correlation of data.

Pathologia 2018; 15 (2), 136-141 DOl: 10.14739/2310-1237 2018.2.141408

E-mail: iryna.zsmu@gmail.com

Киючові слова: ішемічна хвороба серця, постменопаузальний періоА, остеопороз, остеопенічний СИнАрОМ, метаболічні хвороби кісток, взаємозв'язок.

Патологія. - 2018. T. 15, № 2(43). C. 136-141
Objective. To determine the indicators of the bone mineral density (BMD) abnormalities in women with coronary artery disease (CAD) in the post-menopausal period.

Methods. An open cross-sectional study in parallel groups involved 80 women with coronary artery disease (CAD): stable exertional angina of II-III functional class (mean age $64.59 \pm 1.02$ years). Depending on the degree of BMD they were divided into 3 groups: group 1 - 19 CAD women with normal BMD; group 2 - 27 CAD women with osteopenia; group $3-34$ CAD women with osteoporosis. The control selected group consisted of 11 healthy women of the corresponding age. With the help of ultrasound densitometry, FRAX algorithm and bone biomarkers levels assessment we investigated structural and functional state of the bone tissue.

Results. It was acknowledged that in women with CAD in the postmenopausal period, depending on the severity of BMD loss, there is a significant decrease in the T- and Z-criteria and an increase in the 10-year risk of developing osteoporosis fractures. The development of postmenopausal osteoporosis (PMOS) combined with CAD was accompanied with an increase in the level of inflammation, neoangiogenesis and bone remodeling biomarkers (osteoprotegerin, ostecalcin, VEGF-A), which also have multi-directional correlative interrelationships with the structural and functional indicators of the BMD state (T, Z-criterion, 10 -year risk of osteoporosis fractures). ROC-analysis results show the cut-off values at the osteopenia and osteoporosis stage for osteoprotegerin level equal to $223.76 \mathrm{pg} / \mathrm{ml}$ and $224.44 \mathrm{pg} / \mathrm{ml}$; for osteocalcin level $-15.89 \mathrm{ng} / \mathrm{ml}$ and $16.71 \mathrm{ng} / \mathrm{ml}$, for VEGF-A level $-112.52 \mathrm{pg} / \mathrm{ml}$ and $123.31 \mathrm{pg} / \mathrm{ml}$ correspondingly.

Conclusions. The levels of osteoprotegerin and/or ostecalcine and/or VEGF-A can be used as a screening method for early diagnosis of BMD loss and stratification of patients in the category of increased risk of osteopenia and osteoporosis.

\section{Індикатори порушення стану мінералізації кісткової тканини в жінок} у постменопаузальному періоді, які хворі на ішемічну хворобу серця

\section{Н. С. Михайловська, І. О. Стецюк}

Мета роботи - визначити індикатори порушення мінеральної щільності кісткової тканини (МЩКТ) у жінок у постменопаузальному періоді, які хворі на ішемічну хворобу серця (IXC).

Матеріали та методи. У відкрите поперечне дослідження в паралельних групах залучили 80 жінок із діагнозом IXC: стенокардія напруги II-III ФК (середній вік - 64,59 \pm 1,02 року). Залежно від стану МЩКТ хворих поділили на 3 групи: 1 - 19 жінок із нормальними показниками МЩКТ; 2 - 27 жінок з остеопенією; 3 - 34 жінки з остеопорозом. Контрольна група - 11 здорових жінок відповідного віку. За допомогою ультразвукової остеоденситометрії, алгоритму FRAX та оцінювання рівня кісткових біомаркерів вивчили структурно-функціональний стан кісткової тканини.

Результати. У жінок, хворих на IXC, у постменопаузальному періоді залежно від ступеня вираженості порушень МщКТ спостерігали вірогідне зниження Т- та Z-критеріїв і збільшення 10-річного ризику розвитку остеопорозних переломів. Розвиток постменопаузального остеопорозу (ПМОП) на тлі IXC супроводжувався підвищенням рівня біомаркерів запалення, неоангіогенезу та кісткового ремоделювання (остеопротегерину, остекальцину, ВЕФР-А), участь яких у процесах кісткового ремоделювання підтверджувалась наявністю кореляційних взаємозв'язків із показниками, що відбивають структурно-функціональний стан кісток (Т-, Z-критерії, 10-річний ризик розвитку остеопорозних переломів). За допомогою ROC-аналізу визначено критичні точки рівня біомаркерів кісткового ремоделювання щодо розвитку остеопенії та остеопорозу, які для рівня остеопротегерину становили 223,76 пг/мл та 224,44 пг/мл, для рівня остеокальцину 15,89 нг/мл та 16,71 нг/мл, для рівня ВЕФР-А - 112,52 пг/мл та 123,31 пг/мл відповідно.

Висновки. Визначені за допомогою ROC-аналізу рівні остеопротегерину та/або остекальцину та/або ВЕФР-A можуть бути використані для ранньої діагностики порушень структури кісткової тканини та стратифрікації хворих у категорію підвищеного ризику розвитку остеопенії та остеопорозу.

Ключевые слова: ишемическая болезнь сердца, постменопаузальный периоА, остеопороз, остеопенический синаром, метаболические болезни кости, взаимосвязь.

\section{Индикаторы нарушения состояния минерализации костной ткани у женщин в постменопаузальном периоде, страдающих ишемической болезнью сердца}

\section{Н. С. Михайловская, И. О. Стецюк}

Цель работы - определить индикаторы нарушения минеральной плотности костной ткани (МПКТ) у женщин в постменопаузальном периоде, страдающих ишемической болезнью сердца

Материалы и методы. В открытое поперечное исследование в параллельных группах включили 80 женщин с диагнозом ИБС: стенокардия напряжения II-III ФК (средний возраст - 64,59 \pm 1,02 года). В зависимости от состояния 
минеральной плотности костной ткани (МПКТ) все больные разделены на 3 группы: 1 - 19 женщин нормальными показателями МПКТ; 2 - 27 женщин с остеопенией; 3 - 34 женщины с остеопорозом. Контрольную группу составили 11 здоровых женщин соответствующего возраста. С помощью метода ультразвуковой остеоденситометрии, алгоритма FRAX и оценки уровня костных биомаркеров исследовано структурно-фуннццинальное состояние костной ткани.
Патология. - 2018. T. 15, № 2(43). C. 136-141

Результаты. У женщин, страдающих ИБС, в постменопаузальном периоде в зависимости от степени выраженности нарушений МПКТ отмечено достоверное снижение Т- и Z-критериев и увеличение 10-летнего риска развития остеопорозных переломов. Развитие постменопаузального остеопороза (ПМОП) на фоне ИБС сопровождалось повышением уровня биомаркеров воспаления, неоангиогенеза и костного ремоделирования (остеопротегерина, остекальцина, ВЕФР-А), участие которых в процессах костного ремоделирования подтверждается наличием корреляционных взаимосвязей с показателями, отражающими структурно-функциональное состояние костной ткани (Т-, Z-критерии, 10-летний риск развития остеопорозных переломов). При помощи ROC-анализа определены критические точки уровней биомаркеров костного ремоделирования для развития остеопении и остеопороза, которые для уровня остеопротегерина составили 223,76 пг/мл и 224,44 пг/мл, для уровня остеокальцина - 15,89 нг/мл и 16,71 нг/мл, для уровня ВЕФР-А - 112,52 пг/мл и 123,31 пг/мл соответственно.

Выводы. Определенные при помощи ROC-анализа уровни остеопротегерина и/или остекальцина и/или BEФР-A могут быть использованы в качестве скринингового метода ранней диагностики нарушений структуры костной ткани и стратификации больных в категорию повышенного риска развития остеопении и остеопороза.

\section{Introduction}

Coronary artery disease takes the leading place among the diseases of the circulatory system [1,2]: in Europe, its share is about $38 \%$ in the structure of prevalence and $19.5 \%$ in the structure of total mortality $[3,4]$. In Ukraine the CAD prevalence in the adults is $12.2 \%$, and in individuals over the age of 55 this figure increases up to $12.9 \%$ [5]. Despite the achievements of modern medicine, the CAD mortality in Ukraine remains rather high -651.8 per 100 thousand population, which makes $68.9 \%$ of all the diseases of circulatory system $[6,7]$.

In recent years simultaneously with coronary artery disease the problem of osteoporosis has got a special medical and social significance, which is due to the increasing prevalence of this disease due to the aging of the population, the lack of timely detection, prevention and significant impact on the quality of patients' life [8]. The importance of this pathology is also due to its dire consequences - non-traumatic spine and tubular bone fractures, influencing the increase in the disability and mortality of aged patients [8-10].

The development of osteoporosis is based on the processes of pathological bone remodeling, associated with enhanced resorption of mature bone tissue and decreased activity of new bone structures synthesis [11]. It's well known, that remodeling of bone tissue is a dynamic process possessing certain age characteristics. In particular, in women in the first 5-10 years after the menopause onset, the loss of bone mass dramatically increases, and hereinafter (up to 65-70 years) the bone mass decreases on average per $0.3-0.5 \%$ annually [12]. That is why postmenopausal osteoporosis (PMOS), in which the bone mineral density changes are associated with the onset of menopause is one of the most common forms of this pathology [12].

Menopause is not only a proven risk factor for the reduction of bone mineral density (BMD), but also for the progression of cardiovascular diseases. At present, the relationship between osteoporosis (OS) and coronary artery disease in women in the postmenopausal period has been proven [12]. The results of scientific studies convincingly indicate that in osteoporosis, as in atherosclerosis, the similar processes occur, and bone and vascular tissues have a number of common morphological and molecular properties [13]. It has been established that some key proteins of bone metabolism are involved in the pathogenesis of atherosclerosis: osteocalcin, bone morphogenic protein, matrix Gla-protein, osteonectin, sialoprotein, osteopontin and others may be detected in the components of vascular matrix, and in the atherosclerosis progression, the concentration of some of them may significantly increase $[13,14]$. In particular, osteoprotegerin violates the process of osteoclastogenesis and reduces the activity of bone resorption [11], it also acts as an inhibitor of ectopic calcification in patients with coronary artery disease $[11,14,15]$; osteocalcin is an osteoblast activator, however its elevated level is also detected in atherosclerotic plaques [14,16]; vasculoendothelial growth factor $A(V E G F-A)$ is a marker of neoangiogenesis [17], although numerous studies confirm its role in activating osteoclostogenesis and subsequent resorption of bone tissue $[18,19]$. The clinical and pathogenetic role of the identified biomarkers is multidirectional and may vary significantly depending on their concentration in the human body, therefore their participation in the processes of bone remodeling at PMOS requires further study.

\section{Objective}

To determine the indicators of the bone mineral density abnormalities in women with coronary artery disease in the post-menopausal period.

\section{Materials and methods}

The open cross-sectional study in parallel groups involved 80 women with CAD: stable exertional angina of II-III functional class (FC) (mean age 64.59 \pm 1.02 years, mean duration of the postmenopausal period 16.70 \pm 3.35 years).

The diagnosis of CAD and the functional class of stable exertional angina was based on a comprehensive analysis of complaints, data from physical examination, results of laboratory and instrumental studies, in accordance with the National Standards (Order of the Ministry of Health of Ukraine No. 436 dated 03.07.2006, Order of the Ministry of Health of Ukraine No. 152 dated 02.03.2016). 
Table 1. BMD state in women with coronary artery disease in the postmenopausal period, $(\mathrm{M} \pm \mathrm{m})$

\begin{tabular}{|c|c|c|c|}
\hline $\begin{array}{l}\text { Indicator, } \\
\text { units of measurement }\end{array}$ & CAD $(n=19)$ & $\begin{array}{l}\text { CAD + osteopenia } \\
(n=27)\end{array}$ & $\begin{array}{l}\text { CAD + osteoporosis } \\
(n=34)\end{array}$ \\
\hline T-criterion phalanx,SD & $-0.19 \pm 0.17$ & $-1.32 \pm 0.18^{* * *}$ & $-2.20 \pm 0.19^{\star * \star}$ \\
\hline $\mathrm{T}$ - criterion radius, $\mathrm{SD}$ & $-0.38 \pm 0.29$ & $-1.69 \pm 0.16^{* \star *}$ & $-3.10 \pm 0.22^{\star * *}$ \\
\hline T- criterion tibia, SD & $0.15 \pm 0.18$ & $-0.67 \pm 0.22^{* *}$ & $-1.50 \pm 0.32^{* * *}$ \\
\hline Z- criterion phalanx, SD & $1.46 \pm 0.24$ & $0.35 \pm 0.20^{* * *}$ & $-0.18 \pm 0.20^{\star * *}$ \\
\hline Z- criterion radius, SD & $1.25 \pm 0.39$ & $-0.09 \pm 0.17^{\star *}$ & $-1.22 \pm 0.26^{\star * *}$ \\
\hline Z- criterion tibia, SD & $1.85 \pm 0.34$ & $0.86 \pm 0.23^{\star *}$ & $-0.10 \pm 0.33^{\star * *}$ \\
\hline Fracture risk (phalanx), $\%$ & $4.25 \pm 0.59$ & $9.06 \pm 1.00^{* * *}$ & $21.12 \pm 1.89^{* * *}$ \\
\hline Fracture risk (radius), \% & $7.36 \pm 0.9$ & $12.47 \pm 0.89^{* *}$ & $26.79 \pm 2.36^{\star \star}$ \\
\hline Fracture risk (tibia), $\%$ & $10.8 \pm 0.69$ & $12.00 \pm 0.79$ & $17.35 \pm 1.62^{\star *}$ \\
\hline
\end{tabular}

$*, * * * * *$ : the probability of indexes difference if compared to the patients with CAD and normal BMD state $(\mathrm{P}<0.05 ; \mathrm{P}<0.01 ; \mathrm{P}<0.001)$.

Depending on the BMD state, all the patients were divided into 3 groups: group 1 - 19 CAD women with normal BMD (T-criterion is more than $1 \mathrm{SD}$; mean age $64.24 \pm 2.12$ years); group $2-27$ CAD women with osteopenia (T-criterion is from -1 SD to $-2.5 \mathrm{SD}$; mean age $65.22 \pm 1.52$ years); group $3-34 \mathrm{CAD}$ women with osteoporosis (T-criterion is less than -2.5 SD; mean age $69.39 \pm 1.62$ years). The groups were comparable by age, duration of the underlying disease, duration of the postmenopausal period, body mass index (BMI), and the nature of concomitant pathology. The control selected group involved 11 healthy women of the corresponding age.

The research was conducted on the basis of the Cardiology Department and "Health" diagnostic center of the educational and scientific medical center "The University Clinic of Zaporizhzhia State Medical University" (director - MD, PhD, DSc, Professor V. I. Krivenko).

Criteria for the patient to be included into the study were the following: informed consent of the patient, presence of verified (documented) stable exertional angina of II-III FC; the duration of the postmenopausal period in women for more than 5 years.

Exclusion criteria: endocrine pathology (hypogonadism, diabetes, hyperparathyroidism, thyrotoxicosis, acromegaly, hyperprolactinemia, hypercorticism) and diseases inducing the development of secondary osteoporosis; severe chronic somatic pathology; cancer and systemic diseases; mental disorders; alcohol abuse, drug addiction.

All the patients were followed by a clinical examination - a collection of complaints and anamnesis data, physical examination. To assess the degree of the BMD state changes, the ultrasonic osteodensitometry method on the Omnisense 7000 apparatus with sensors for the phalanx of the finger, the radial and tibia bone was applied. Diagnosis of osteoporosis was performed according to $\mathrm{WHO}$ criteria. The degree of BMD state changes was evaluated according to the T-criterion (the magnitude of the standard deviations - SD from the mean values of the "peak bone mass"): the decrease in BMD up to -1 SD was regarded as normal rate, from -1 to $-2.5 \mathrm{SD}$ - as osteopenia, more than $-2.5 \mathrm{SD}$ - osteoporosis. This method as a screening method in diagnostics of BMD disorders was chosen due to its convenience and simplicity. The FRAX algorithm was used to assess the 10-year risk of osteoporotic fractures development. On the basis of Medical and Laboratory Training Center ZSMU (Director - MD, PhD, DSc Profes- sor A. Abramov) using ELISA method on enzyme-linked immunosorbent analyzer "SIRIO S" (Italy) the levels of osteocalcin (a set of reagents by Bender MedSystems $\mathrm{GmbH}$, Austria), osteoprotegerin (set of reagents by Immudiagnostic systems limited, England), VEGF-A (eBioscience, An Affymetrix Company, USA) were measured.

In the following study the principles of bioethics were respected: the main provisions of the European Convention on Human Rights and Biomedicine (from 04.04.1997), GCP (1996), Helsinki Declaration of the World Medical Association on the Ethical Principles of Human Medical Scientific Research (1964-2000) and the Ministry of Health of Ukraine Order No. 281 dated back to 01.11 .2000 . The study protocol was approved by the Ethics Committee of the Zaporizhzhia State Medical University, Ukraine.

Statistical data processing was carried out by using the method of variation statistics with the help of software package Statistica 10.0. (StatSoft Inc., № AXXR712D833214FAN5), under the generally accepted practice. The nature of the distribution of the studied variables was assessed using the Shapiro-Wilk test. Quantitative characteristics were represented as $\mathrm{M} \pm \mathrm{m}$ (arithmetic mean \pm standard error of arithmetic mean) or Me (Q25; Q75) (median, 25 and 75 distribution quartiles) depending on the type of the distribution. Under normal distribution, the validity of the differences was estimated using the Student's t-criterion; in the distribution different from normal, Mann-Whitney non-parametric U-test was used. Assessment of the interrelationship between pairs of independent indexes, expressed in quantitative scale, was performed by calculating Pearson rank correlation coefficients (in normal distribution) and Spearman's rank correlation coefficients (in the distribution different from normal). To assess the diagnostic significance, the ROC-analysis (Receiver Operating Characteristic) with a construction of the characteristic curves of the sensitivity and specificity of the investigated features dependence and the calculation of the area under the working characteristic curve (AUC) was used. To determine the risk of developing BMD disorders, calculations of relative risk was performed in patients with increased level of the bone remodeling biomarkers compared with patients with normal indices by constructing four-fold tables. Differences were considered statistically significant at $\mathrm{P}<0.05$.

\section{Results}

The results of the assessment of the BMD state, obtained by ultrasound osteodensitometry in women with coronary artery disease in the postmenopausal period, are presented in Table 1.

It was acknowledged that in women with CAD in the postmenopausal period, depending on the severity of BMD loss, a significant decrease in the T- and Z-criteria and an increase in the 10-year risk of osteoporosis fractures development were observed, thus confirming the presence of osteopenia or osteoporosis in the corresponding group.

The level of biomarkers of bone remodeling in women with $C A D$ in the postmenopausal period is presented in Table 2. 
Table 2. Levels of bone remodeling biomarkers in postmenopausal women with coronary artery disease, depending on the degree of BMD loss, $\operatorname{Me}\left(Q_{25} ; Q_{75}\right)$

\begin{tabular}{l|l|l|l|l} 
Indicator, units of measurement & Control selected group $(\mathbf{n}=11)$ & CAD $(\mathbf{n}=1 \mathbf{1 9})$ & CAD + osteopenia $(\mathbf{n}=\mathbf{2 7})$ & CAD + osteoporosis $(\mathbf{n}=\mathbf{3 4})$ \\
\hline Osteocalcin, $\mathrm{ng} / \mathrm{ml}$ & $14.24(12.54 ; 17.12)$ & $15.66(12.75 ; 18.04)$ & $16.55(9.95 ; 25.51) \#^{*}$ \\
\hline Osteoprotegerin, pg/ml & $216.85(170.58 ; 231.35)$ & $221.69(213.40 ; 232.74)$ & $227.9(196.82 ; 241.02) \#$ \\
\hline VEGF-A, pg/ml & $119.74(102.66 ; 321.86)$ & $119.84(77.05 ; 225.21)$ & $190.19(96.76 ; 243.54) \#$ \\
\hline
\end{tabular}

\#: the probability of indexes difference if compared to the control selected group $(\mathrm{P}<0.05) ; *, * *, * * *$ : the probability of indexes difference if compared to the patients with CAD and normal BMD state $(P<0.05 ; P<0.01 ; P<0.001)$.

In women with $\mathrm{CAD}$, in parallel with the decrease in BMD state, a significant increase in the bone remodeling biomarkers level was observed: an increase in osteocalcin level by $16.22 \%$ and by $5.68 \%$ in the CAD and osteopenia group, by $19.52 \%$ and by $8.68 \%$ in the group of women with coronary artery disease and osteoporosis correspondingly if compared to the control selected group $(P<0.05)$ and the group of women with coronary artery disease and normal BMD state $(P<0.05)$. The level of osteoprotegerin also increased if compared to the control selected group: by $5.10 \%$ in the group of women with coronary artery disease and osteopenia, by $6.53 \%$ in the group of women with coronary artery disease and osteoporosis $(P<0.05)$. This biomarker trended to increase in women with coronary artery disease and osteoporosis compared with women with coronary artery disease and normal BMD state.

An increase in the VEGF-A level was observed: 1.9 times higher in the group of women with coronary artery disease and osteopenia, 1.5 times higher in the group of women with coronary artery disease and osteoporosis if compared to the control selected group and patients with CAD and normal BMD respectively $(P<0.05)$.

Under the conduction of the correlation analysis in the group of women with coronary artery disease and osteoporosis, a direct correlative dependence between the level of osteoprotegerin and the 10-year risk of fracture of the radial bone $(r=+0.46 ; P<0.01)$, between the level of osteocalcin and the risk of fracture of the tibia $(r=+0.40$; $\mathrm{P}<0.05$ ) was discovered; the inverse correlative dependence between the level of VEGF-A and the T-criterion of the radial bone $(r=-0.57 ; P<0.05)$, between the level of osteoprotegerin and the T-criterion of the radial bone $(r=-0.63 ; P<0.01)$, T-criterion tibia $(r=-0.52 ; P<0.01)$, Z-criterion radius $(r=-0.62 ; P<0.01)$, Z-criterion tibia $(r=-0.51 ; P<0.01)$ was found out.

In the group of women with coronary artery disease and osteopenia, the inverse correlative dependence between the level of osteoprotegerin and the T-criterion of phalanx was discovered $(r=-0.46 ; P<0.05)$; a direct correlative dependence between the level of osteocalcin and the risk of fractures of the radial bone $(r=+0.47$; $\mathrm{P}<0.05$ ) was discovered.

In order to determine the optimal threshold values of bone remodeling biomarkers as indicators of BMD disorders at different stages, the ROC analysis was conducted and the critical value of osteoprotegerin level equal to $223.76 \mathrm{pg} / \mathrm{ml}(\mathrm{Se}=70.0 \%, \mathrm{Sp}=71.4 \%, \mathrm{AUC}=0.787$, $95 \% \mathrm{Cl} 0.637-0.896$ ) was found out, which indicates the onset of development of BMD loss at the osteopenia stage. Also the critical value of the osteoprotegerin level for osteoporosis was found out to be equal to $224.44 \mathrm{pg} / \mathrm{ml}$ $(\mathrm{Se}=67.6 \%, \mathrm{Sp}=68.9 \%, \mathrm{AUC}=0.762,95 \% \mathrm{Cl}$
0.619-0.872). The ROC-curves of the osteoprotegerin level at the stage of osteopenia and osteoporosis are presented in Fig. 1 ( $A, B)$.

For the osteocalcin level, the corresponding critical values were $15.89 \mathrm{ng} / \mathrm{ml}(\mathrm{Se}=83.3 \%, \mathrm{Sp}=81.0 \%$; AUC $=0.875 ; 95 \% \mathrm{Cl} 0.742-0.955)$ and $16.71 \mathrm{ng} / \mathrm{ml}(\mathrm{Se}=$ $65.6 \%, \mathrm{Sp}=77.8 \%, \mathrm{AUC}=0.844,95 \% \mathrm{Cl} 0.713-0.931$ ).

The ROC-curves of the osteocalcin level at the stage of osteopenia and osteoporosis are presented in Fig. 2 (A, B).

The ROC-curves of the VEGF-A level at the stage of osteopenia and osteoporosis are presented in Fig. 3 (A, B).

According to the ROC-analysis results, the critical value of VEGF-A level in osteopenia identification was equal to $112.52 \mathrm{pg} / \mathrm{ml}(\mathrm{Se}=88.9 \%, \mathrm{Sp}=82.4 \%$; AUC $=0.952 ; 95 \% \mathrm{Cl} 0.842-0.994)$, in osteoporosis identification $-123.31 \mathrm{pg} / \mathrm{ml}(\mathrm{Se}=85.7 \%, \mathrm{Sp}=94.3 \%$, AUC $=0.964,95 \% \mathrm{Cl} 0.869-0.996)$. That is, the VEGF-A level is the most sensitive indicator, which represents the possibility of BMD disorders development, beginning with the osteopenic stage, when clinical manifestations of the disease are absent.

Subsequently, the analysis of relative risk was performed and it was found out that the increase in the osteoprotegerin level is associated with the 1.6 times increase of osteopenia development risk $(R R=1.626$; $95 \% \mathrm{Cl} 1.014-2.607 ; \mathrm{P}<0.05)$ and 1.9 times increase of osteoporosis development risk ( $\mathrm{RR}=1.941 ; 95 \% \mathrm{Cl}$ 1.134-3.322; $\mathrm{P}<0.05)$. For osteocalcin, the related risk was $1.8(\mathrm{RR}=1.750 ; 95 \% \mathrm{Cl} 1.014-3.019 ; \mathrm{P}<0.05)$ and 1.7 times (RR $=1.729 ; 95 \% \mathrm{Cl} 1.052-2.841 ; \mathrm{P}<0.05)$, and for VEGF-A-2.2 (RR = 2.167; $95 \% \mathrm{Cl}$ 1.109-4.235; $\mathrm{P}<0.05)$ and $1.6(\mathrm{RR}=1.556 ; 95 \% \mathrm{Cl} 1.008-2.401$; $\mathrm{P}<0.05)$ times correspondingly.

\section{Discussion}

In our study, an increase in the level of osteocalcin was found, which according to literature data, may indicate a violation of its inclusion in the normal structure of bone tissue, compensatory activation of osteoblasts on the background of decreased BMD and its participation in the process ectopic calcification of the heart and blood vessels $[12,16]$.

The increase of the osteoprotegerin level can be explained by the participation in the process of osteoclastogenesis inhibition and bone tissue resorption, as well as its compensatory enhancement to perform a protective role in the development of vascular calcification, which confirms the opinion of other authors $[11,15]$.

It's generally known that VEGF-A is not only a regulator of neoanogeogenesis and a stimulator of blood supply 
$1 \mathrm{~A}$ level_of_osteoprotegerin_pg_ml

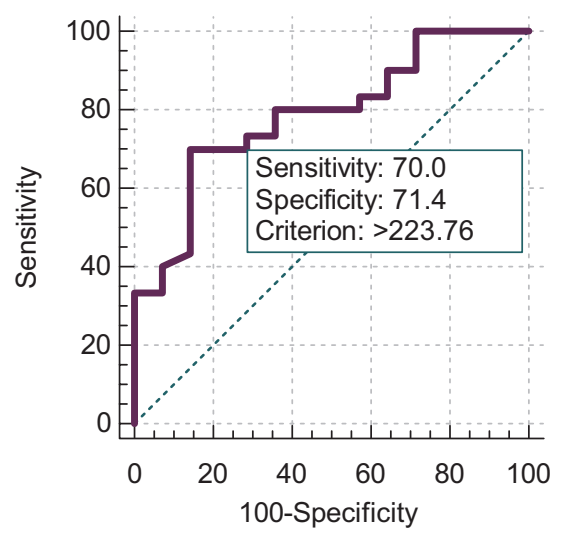

$2 A$

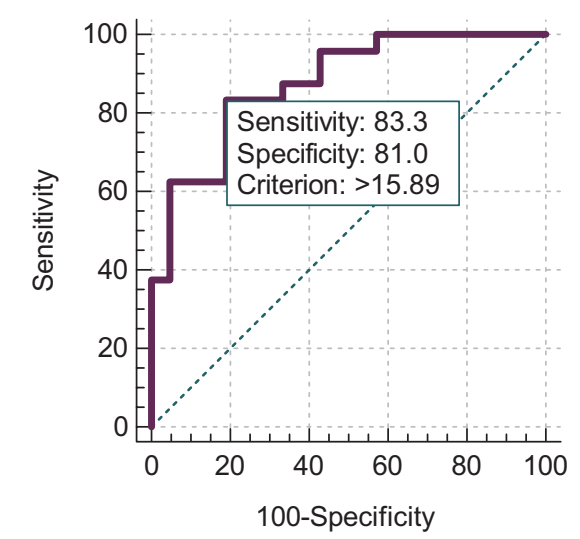

$3 A$ level_of_VEGF_pg_ml

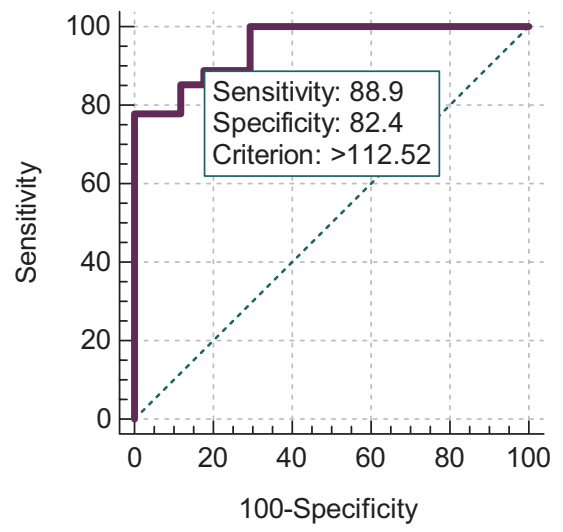

1B level_of_osteoprotegerin_pg_ml

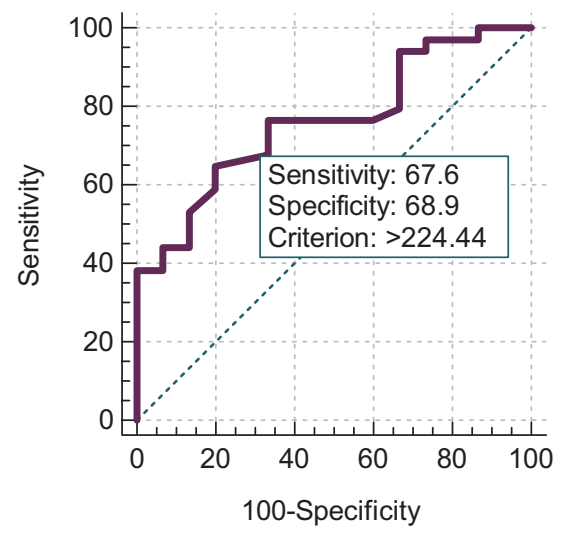

2B

$$
\text { level_of_osteocalcin_ng_ml }
$$

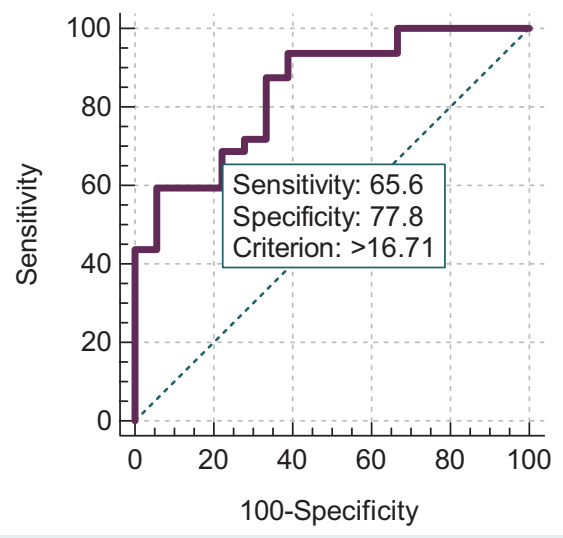

3B

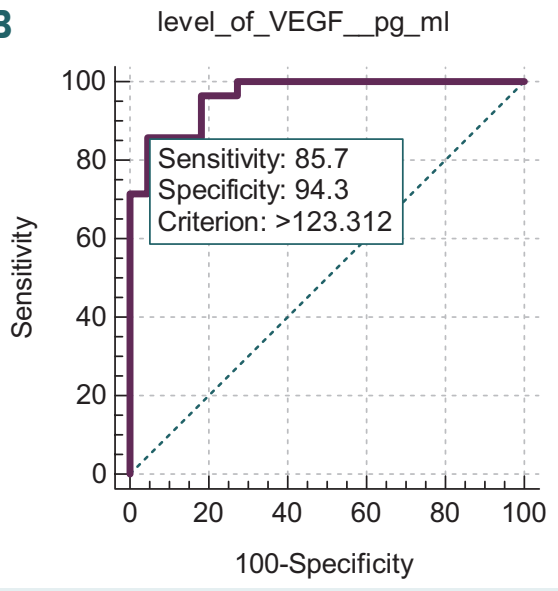

Fig. 1. The ROC-curves of the osteoprotegerin level at the stage of osteopenia (A) and osteoporosis (B), in comparison with a group of patients with $C A D$ and normal BMD state.

Fig. 2. The ROC-curves of the osteocalcin level at the stage of osteopenia (A) and osteoporosis $(B)$, in comparison with a group of patients with $C A D$ and normal BMD state.

Fig. 3. The ROC-curves of the VEGF-A level at the stage of osteopenia (A) and osteoporosis (B), in comparison with a group of patients with CAD and normal BMD state. to bone and cartilage tissues $[17,18]$, but also acts as the osteoclastogenesis stimulator [19].

The VEGF-A level changes revealed in our study may be explained by the fact that in the conditions of the development of chronic tissue hypoxia in CAD there is an overexpression of the VEGF-A level [20], which leads to the malfunction of the normal molecular mechanisms of the ossification development, activation of osteoclastogenesis with the subsequent stimulation of osteoclast-mediated bone resorption [19].

According to scientific data, there is a close relationship between processes of osteogenesis, cardiovascular diseases development and progression of endothelial dysfunction $[11,13,14,18,20]$. This point of view is also confirmed by our correlation analysis results. The results of ROC analysis indicate the expediency of determining the concentration of any of the above-mentioned biomarkers and/or their combination as a screening marker for BMD loss and determining the degree of its severity.

Thus, the obtained data confirm the general pathogenetic bases of development of BMD disorders, the growth of levels of bone remodeling biomarkers and the progression of endothelial dysfunction in postmenopausal women with CAD. 


\section{Conclusions}

1. The development of PMOS combined with $C A D$ is accompanied with an increase in the level of inflammation, neoangiogenesis and bone remodeling biomarkers (osteoprotegerin, ostecalcin, VEGF-A).

2. The presence of multi-directional correlative interrelationships between the level of osteoprotegerin, osteocalcin, VEGF-A with the structural and functional indicators of the BMD state (T, Z-criterion, 10-year risk of osteoporosis fractures) suggests the participation of these biomarkers in the processes of bone remodeling.

3. The levels of osteoprotegerin and/or ostecalcine and/or VEGF-A determined by the ROC analysis can be used as a screening method for early diagnosis of BMD loss and stratification of patients in the category of increased risk of osteopenia and osteoporosis development.

Prospects for further research: to assess the impact of basic CAD therapy (with the addition of drugs that affect the state of bone mineralization state) on the reduction of the osteoporotic fractures risk.

Conflicts of Interest: authors have no conflict of interest to declare. Конфлікт інтересів: віАсутній.

Information about authors:

Mykhailovska N. S., MD, PhD, DSc, Professor, Head

of the Department of General Practice - Family Medicine,

Zaporizhzhia State Medical University, Ukraine.

Stetsiuk I. O., MD, Clinical Ordinator of the Department of General Practice - Family Medicine, Zaporizhzhia State Medical University, Ukraine.

\section{Відомості про авторів:}

Михайловська Н. С., А-р меА. наук, професор, зав. каф. загальної практики - сімейної меАицини, Запорізький Аержавний медичний університет, Україна.

Стецюк І. 0., кмінічний ординатор каф. загальної практики - сімейної медицини, Запорізький Аержавний медичний університет, Україна.

\section{Сведения об авторах:}

Михайловская Н. С., А-р меА. наук, профессор, зав. каф. общей практики - семейной медицины, Запорожский государственный медицинский университет, Украина. Стецюк И. О., клинический ординатор каф. общей практики - семейной медицины, Запорожский государственный медицинский университет, Украина.

Надійшла Ао редакції / Received: 26.06.2018

Після Аоопрацювання / Revised: 20.07.2018

Прийнято Ао Аруку / Accepted: 17.08.2018

\section{References}

[1] Horbas, I. M. (2009). Ishemichna khvoroba sertsia: epidemiolohiia i statystyka [Coronary heart disease: epidemiology and statistics]. Zdorovia Ukrainy, 3/1, 34-35. [in Ukrainian].

[2] Grasgruber, P., Sebera, M., Hrazdira, E., Hrebickova, S., \& Cacek, J. (2016). Food consumption and the actual statistics of cardiovascular diseases: an epidemiological comparison of $42 \mathrm{Eu}-$ ropean countries. Food \& nutrition res., 60(1), 31694. doi: 10.3402/ fnr.v60.31694.

[3] Townsend, N., Wilson, L., Bhatnagar, P., Wickramasinghe, K., Rayner, M., \& Nichols, M. (2016). Cardiovascular disease in Europe: epidemiological update 2016. Eur. Heart J., 37(42), 3232-3245. doi: 10.1093/eurheartj/ehw334.
[4] Wilkins, E., Wilson, L., Wickramasinghe, K., Bhatnagar, P., Leal, J., Luengo-Fernandez, R., et al. (2017). European Cardiovascular Disease Statistics 2017. Brussels: European Heart Network.

[5] Kovalenko, V. M., \& Kornatskyi, V. M. (2016) Problemy zdorovia medychnoi dopomohy ta model pokrashennia v suchasnykh umovakh [The problems of health and medical help and the improvement model in the modern conditions]. Kyiv: Hordon. [in Ukrainian].

[6] Kovalenko, V. M., \& Dorogoi, A. P. (2016) Sertsevo-sydynni khvoroby: medychno-sotsialne znachennia ta stratehiia rozvytky kardiolohii $v$ Ukraini [Cardiovascular diseases: medical and social meaning and development strategy for cardiology in Ukraine]. Ukrainskyi kardiolohichnyi zhurnal, 3(74), 5-14. [in Ukrainian].

[7] Fuster, K., \& Kelly, B. B. (Eds.) (2010). Institute of medical committee on preventing the global epidemic of cardiovascular disease: meeting the challenges in developing countries. Washington: National Academies Press.

[8] Barna, O. M. Yarema, N. I., Bazylevych, A. Ya. (2009). Patofiziolohichni ta klinichni paraleli IKhS ta osteoporozu [Pathophysiological and clinical coronary heart disease and osteoporosis parallel]. Liky Ukrainy, (3,129), 43-46. [in Ukrainian].

[9] Povoroznyuk, V. V., Garkusha, M. A., Bystritskaya, M. A., \& Balatskaya, N. I. (2012) Mineralna shilnist kistkovoi tkanyny proksimalnoho viddilu stehnovoi kistky v patsientok z perelomom Kollisa [Bone mineral density proximal femur fractures in patients with Colles' fracture]. Problemy osteolohii, 15(4), 53-59. [in Ukrainian].

[10] Toropcova, N. V. (2012) Shto my znaem ob e'ffectivnosti rizendronata pri osteoporoze [What do we know about rizendronate effectiveness in osteoporosis]. Zdorov'e zhenschiny, 1(67), 87-89. [in Russian].

[11] Sagalovsky, S., \& Richter, T. (2012). Patofiziologicheskoe edinstvo kletochno-molekulyarnykh mekhanizmov razvitiya osteoporoza i ateroskleroza sosudov [Pathophysiological entity of cellulomolecular mechanisms of development of osteoporosis and atherosclerosis of vessels]. Mizhnaronyi medychnyi zhurnal, 18(4), 71-78. [in Russian].

[12] Gavisova, A. A., Tverdikova, M. A., \& Yakushevskaya, O. V. (2012). Osteoporoz: sovremennyj vzglyad na problemu [Osteoporoz: a modern view on a problem]. Russkij medicinskij zhurnal, 20(21), 1110-1116. [in Russian].

[13] Vertkin, A. L., Naumov, A. V., Goruleva, E. I., Adonina, E. V., Skotnikov, A. S., Shakirova, S. R., et al. (2012). Osteoporoz kak komponent serdechno-sosudistogo kontinuuma [Osteoporosis as component of a cardiovascular continuum]. Lechashchij vrach. Retrieved from http:// www.lvrach.ru/2012/02/15435341. [in Russian].

[14] Mykhailovska, N. S., Stetsiuk, I. O., Zelenina, O. O., \& Nikitiuk, O. V. (2016). Doslidzhennia osoblyvostei sertsevo-sudynnoho remodeliuvannia ta zminy markeriv metabolizmu kistkovoi tkanyny u zhinok z ishemichnoiu khvoroboiu sertsia, asotsiiovanoiu z postmenopauzalnym osteoporozom [Research of the features of cardiovascular remodeling and bone tissue metabolism markers changes in women with coronary artery disease, associated with postmenopausal osteoporosis]. ScienceRise: Medical Science, 8(4), 51-58. [in Ukrainian]

[15] Karpova, I. S. (2012). Vzaimosvyaz' kal'cinoza arterij i klapannogo apparata serdca i osteoporoza [Interrelation of a kaltsinoz of arteries and the valvate device of heart and Osteoporosis]. Kardiologiya $v$ Belarusi, 1(20), 98-104. [in Russian].

[16] Pankratova, Yu. V., Pigarova, E. A., \& Dzeranova, L. K. (2013). Vitamin K-zavisimye belki: osteokal'cin, matriksnyj Gla-belok i ikh vnekostnye e'ffekty [Vitamin K-dependent proteins: osteocalcin, matrix Gla-protein, and their non-bone effects]. Ozhirenie imetabolism, 2, 11-18. [in Russian].

[17] Zhavrid, E'. A., Antonenkova, N. N., Prokhorova, V. I., \& Lappo, S. V. (2010). Koncentraciya sosudistogo e'ndotelial'nogo faktora rosta $v$ syvorotke krovi bol'nykh metastaticheskim rakom molochnoj zhelezi i chuvstvitel'nost' opykholi k citostaticheskoj terapii [Level of vascular endothelial growth factor in the serum of patients with metastatic breast cancer and the sensitivity of the tumor to cytostatic therapy]. Onkologicheskij zhurnal, 4, 2(14), 23-28. [in Russian].

[18] Mohylnytska, L. A. (2015) Vaskyloendotelialnyi faktor rostu ta endoteliizalezhna dylatatsiia u khvorykh z dytynstva na tsukrovyi diabet 1 typu z mikroanhiopatiiamy ta v osib molodoho viku z ozhyrinniam [Vasculoendothelial growth factor and endothelium-dependent dilation in patients with juvenile diabetes mellitus type 1 with microangiopathies and in young patients with obesity]. Klinichna endokrynolohiia ta endokrynna khirurhiia, 3(51), 23-29. [in Ukrainian]

[19] Grosso, A., Burger, M. G., Lunger, A., Schaefer, D. J., Banfi, A., \& Di Maggio, N. (2017) It Takes Two to Tango: Coupling of Angiogenesis and Osteogenesis for Bone Regeneration. Front. Bioeng. Biotechnol., 5, 68. doi: 10.3389/fbioe.2017.00068.

[20] Koval,' S. N., Snegurskaya, I. A., \& Mysnichenko, O. V. (2012). Semejstvo vaskuloe'ndotelial'nogo faktora rosta i ego vozmozhnaya rol' $\checkmark$ patogenese arterial'noj gipertenzii [Vasculoendothelial growth factor family and its possible role in the oathogenesis of arterial hypertension]. Arterial'naya gipertensiya, 4(24). Retrieved from http://www.mif-ua.com/ archive/article/33320. [in Russian]. 